\title{
Screening of endoglucanase-producing bacteria in the saline rhizosphere of Rhizophora mangle
}

\author{
André Luís Braghini Sá ${ }^{1,2}$, Armando Cavalcante Franco Dias ${ }^{2,3}$, \\ Maria Carolina Quecine ${ }^{4}$, Simone Raposo Cotta ${ }^{3}$, Cristiane Cipola Fasanella ${ }^{3}$, \\ Fernando Dini Andreote ${ }^{3}$, Itamar Soares de Melo ${ }^{2}$ \\ ${ }^{1}$ Centro de Pequisas Biológicas, Universidade de São Paulo, São Paulo, SP, Brazil. \\ ${ }^{2}$ Laboratório de Microbiologia Ambiental, Embrapa Meio Ambiente, Jaguariúna, SP, Brazil. \\ ${ }^{3}$ Departamento de Ciência dos Solos, Escola Superior de Agricultura "Luiz de Queiroz", \\ Universidade de São Paulo, Piracicaba, SP, Brazil. \\ ${ }^{4}$ Departamento de Genética, Escola Superior de Agricultura "Luiz de Queiroz", \\ Universidade de São Paulo, Piracicaba, SP, Brazil.
}

Submitted: February 3, 2012; Approved: September 9, 2013.

\begin{abstract}
In screening the culturable endoglucanase-producing bacteria in the rhizosphere of Rhizophora mangle, we found a prevalence of genera Bacillus and Paenibacillus. These bacteria revealed different activities in endoglucolysis and biofilm formation when exposed to specific $\mathrm{NaCl}$ concentrations, indicating modulated growth under natural variations in mangrove salinity.
\end{abstract}

Key words: Bacillus, Paenibacillus, ecological behavior.

Mangrove ecosystems have been described as an environment with a particular combination of characteristics, mainly related to salinity and anaerobiosis (Al-Sayed et al., 2005; Lawson, 2011), where a single microbial community composition may reside (Dias et al., 2009a, 2011b; Peixoto et al., 2011; Santos et al., 2011). Thus these ecosystems are promising for screening organisms with possible biotechnological applications (Holguin et al., 2001). The most common plant species found in mangroves is Rhizophora mangle (Schaeffer-Novelli et al., 2000), which have a particular rhizosphere system, where bacteria must withstand the environment in order to promote plant growth.

Along these lines, it is important to consider the bacteria's ability to promote organic matter degradation, providing nutrients for the host plant. Thus, functionality in such an ecosystem makes screening for cellulose-degraders organisms interesting, since such organisms may be producers of important biotechnological enzymes, such as endoglucanases (Cunha et al., 2005). Dias et al. (2009) stressed the presence of such an enzymatic arsenal in mangrove-inhabiting microorganisms and its important application in biotechnological tools. Here we present a survey on the culturable bacterial community that advantageously have the ability to produce endoglucanase when found in the rhizosphere of $R$. mangle, and link this process with salinity level and biofilm formation.

The mangrove rhizosphere samples used were obtained from lateral and aerial $R$. mangle roots (nutrition roots) sampled in two mangroves located in the State of São Paulo (Brazil); one located in a well-preserved area (in the city of Cananéia, $22^{\circ} 42^{\prime} 01^{\prime \prime} \mathrm{S}, 46^{\circ} 58^{\prime} 58^{\prime \prime} \mathrm{W}$ ), and another located in an oil-contaminated site (city of Bertioga, $23^{\circ} 53^{\prime} 80^{\prime \prime} \mathrm{S}$ and $46^{\circ} 12^{\prime} 46^{\prime \prime} \mathrm{W}$ ). For each sample, roots immersed in the sediment (depth of 10 to $15 \mathrm{~cm}$ ) were removed and stored in plastic bags and brought to the laboratory $\left(4{ }^{\circ} \mathrm{C}\right.$ during transport for an average of $\left.12 \mathrm{~h}\right)$. The rhizosphere was considered soil adhered to roots, avoiding liquefied/muddy soil.

Approximate 1-g aliquots of rhizosphere were diluted into $9 \mathrm{~mL}$ of sterilized saline solution $(0.9 \% \mathrm{NaCl})$ and homogenized under agitation ( $1 \mathrm{~h}$ at $150 \mathrm{rpm})$. The resulting suspensions were used to plate in solid Nutrient Agar $\left(\mathrm{NA}{ }^{\circledR} \mathrm{BBL}\right)$ medium. The plates were incubated at $28^{\circ} \mathrm{C}$ for seven days and the number of bacterial colonies was deter-

Send correspondence to A.C.F. Dias. Departamento de Ciência dos Solos, Escola Superior de Agricultura "Luiz de Queiroz", Universidade de São Paulo, Piracicaba, SP, Brazil. E-mail: dias147@gmail.com. 
mined. Abundance and diversity of groups of colonies was obtained from rhizosphere samples by estimating Log values of 8.07 and $7.53 \mathrm{cfu}^{-\mathrm{g}^{-1}}$ from rhizosphere of plants collected in Cananéia and Bertioga, respectively.

Endoglucolytic isolates were selected according to the methodology described by Theather and Wood (1982). Briefly, culture plates containing $1 \%$ carboxymethylcellulose (CMC) were used for culturing bacteria. After incubating at $28{ }^{\circ} \mathrm{C}$ during 4 days, plates were covered with Congo Red solution (1\%) for $15 \mathrm{~min}$ and then washed with $\mathrm{NaCl} 5 \mathrm{M}$. Endoglucolytic activity was observed as formation of clear zones around the colonies. Isolates classified as positive for endoglucanase production were subjected to enzymatic activity quantification by spectrophotometry, as described by Wirth and Ulrich (2002). This approach resulted in a selection of 30 endoglucanase-producers (out of 129 colonies screened), of which 22 were isolates from Cananéia and 8 from Bertioga. Endoglucolytic activity quantification revealed isolates 39a and 60a (both from samples collected in the Cananéia mangrove) to have the highest endoglucanase production rates, with enzymatic indexes (halo/colony diameter) of 2.0 for both strains, and quantification values of 0.641 and 0.426 (absorbance at $600 \mathrm{~nm}$ ), respectively.

The 30 selected isolates were identified by fatty acid methyl ester (FAME-MID), as described by Dias et al. (2009), using the database TSBA60 as a model. The order Bacillales was most common (except for two Actinobacteria isolates and two that remained unidentified). The isolates from Cananéia were identified as Paenibacillus sp., P. macerans, P. lentimorbus, B. pumilus, B. subtilis, and Streptomyces sp., and the isolates from Bertioga were identified as P. macerans, B. pumilus, B. sphaericus, and Curtobacterium flaccumfaciens.

Bacteria from the genera Bacillus and Paenibacillus have been reported to be associated with mangrove plants by Holguin et al. (2001), who verified phosphate solubilized by $B$. athrophaeus and P. macerans associated with Avicennia marina. Another study verified Bacillus spp. isolates from rhizosphere of $R$. mangle and Laguncularia racemosa that were able to degrade polycyclic aromatic hydrocarbons (PAH) (Maciel-Souza et al., 2006). Here, we describe the abundance of bacteria belonging genus associated with the rhizosphere of the most abundant tree species in mangroves ( $R$. mangle), and present their ecological role of endoglucolytic activity.

One isolate (39a - identified as B. subtilis), selected for its high endoglucanase yield, was further analyzed to determine the role of salinity variation on endoglucanase production and bacterial biofilm formation. This was done by recreating the conditions in $R$. mangle rhizosphere, where salinity is variable over time. The 39 a isolate was cultivated in Nutrient Broth ( $\mathrm{NB}^{\circledR} \mathrm{BBL}$ ) medium supplemented with $\mathrm{NaCl}$ at the following concentrations: $3 \%$ (0.5 M), 5\% (0.8 M), 7\% (1.2 M), 10\% (1.7 M), 15\%
(2.5 M), and 20\% (3.4 M). Bacterial development was monitored by spectrophotometry (at $550 \mathrm{~nm}$ ) at 2, 4, 10, 16, 24 , and $48 \mathrm{~h}$ after inoculation.

Assessing the cell development indicates that saline concentrations modulate bacterial reproduction; where the $\log$ was observed after two hours of culture in the medium without $\mathrm{NaCl}$, and at higher $\mathrm{NaCl}$ concentrations $(7,10$, and $15 \% \mathrm{NaCl}$ ), the log phase is observed only after four hours after inoculation. Culturing at $20 \% \mathrm{NaCl}$ demonstrated that, in liquid medium, this amount of salt has an inhibitory effect on bacterial growth. The literature states that organisms affiliated with the class Bacillales are salt-tolerant, being able to grow at $24 \% \mathrm{NaCl}$ (Pooja and Mugeraya 2011; Ventosa et al., 1998). It is important to note that the ability to grow under high saline conditions represents an important feature in the interaction between bacteria and $R$. mangle, which is also a halotolerant plant due to the presence of subterranean roots that can filter the water prior to uptake (Fruehaf, 2005).

Additionally, cultures of the 39a isolate in solid medium were used to determine changes in the fatty acid methyl ester profiles when cells are cultivated under distinct $\mathrm{NaCl}$ concentrations of (using the same concentrations but analyzed $48 \mathrm{~h}$ after plating). The results from both cultivation approaches (solid and liquid) revealed similar results, where among the 11 FAMEs detected, one shifted in abundance in solid culture ( $\left.\mathrm{aiC}_{15}\right)$, and two changed in abundance when cells were exposed to $\mathrm{NaCl}$ in liquid medium ( $\mathrm{aiC}_{15}$ and $\left.\mathrm{nC}_{16}\right)$ (Table 1). Changes were always related with the proportional increase of such FAMEs with $\mathrm{NaCl}$ concentration. The genus Bacillus was predominant in terminally methyl-branched saturated iso and anteiso fatty acids, with carbon chains varying between 12 and 17 carbons (Kaneda, 1977). The structural changes of membranes indicate that their structures are responsive to salinity changes, possibly preventing $\mathrm{NaCl}$ from entering, consequently protecting cells from leaking osmolites. This result corroborates data from Nicolaus et al. (2001), who proposed that increased salinity leads to increased internal osmotic pressure.

Other than cell development and FAMEs profiles, endoglucolytic activity was also quantified when bacteria were grown at different salinity levels, where the highest value was obtained in the medium with $7 \% \mathrm{NaCl}$, followed by a steep decrease in $\mathrm{NaCl}$ concentration when at $10 \%$. The lowest endoglucanase yield by cells cultivated in higher $\mathrm{NaCl}$ concentrations could be related to the lower cell count per gram of medium (reducing halos and quantification), or due to a cell response to salt presence. As shown below, the increase in salt concentration also led increased biofilm formation. Thus, the high abundance of exopolysacharides (EPS) in biofilms could be related to a lower endoglucanase yield by biofilm-protected cells.

Moreover, colonies of this isolate growing at different saline concentrations were subjected to scanning elec- 


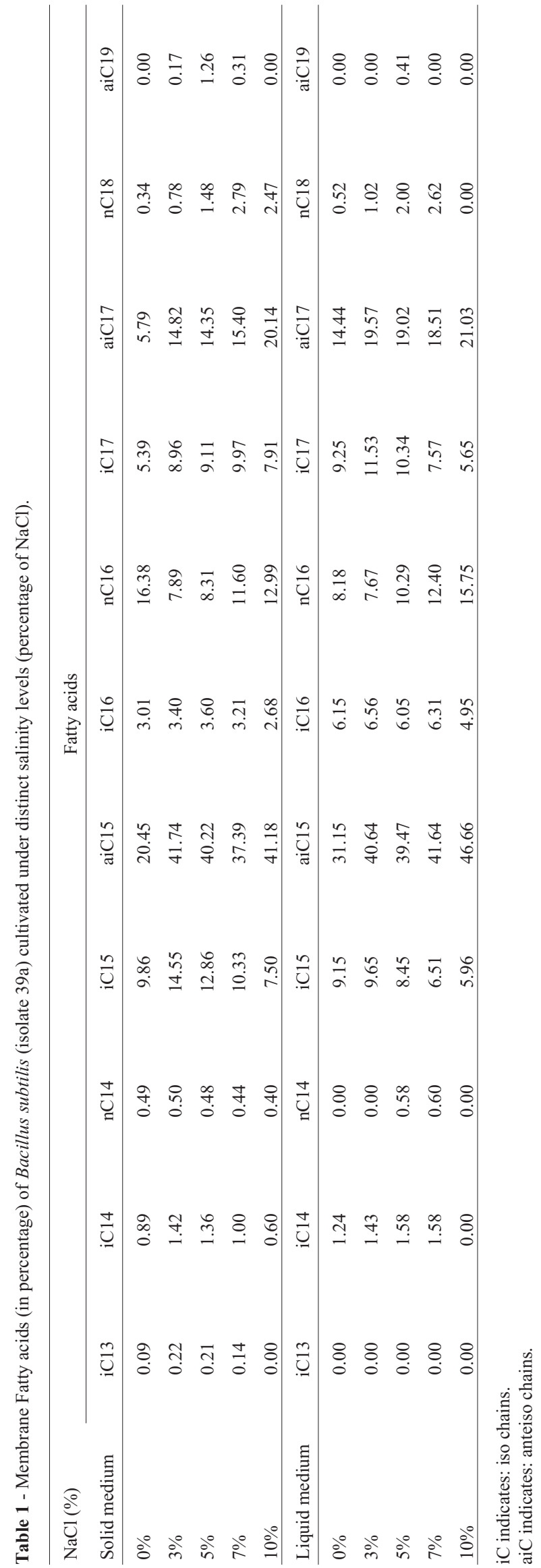

tron microscopy. In order to properly prepare the material, samples were obtained from solid cultures, and fixed for $2 \mathrm{~h}$ at $28{ }^{\circ} \mathrm{C}$ under vacuum $(760 \mathrm{~mm} \mathrm{Hg})$ and using $2.5 \%$ glutaraldheide and $0.2 \mathrm{M}$ cacodilate buffer, $\mathrm{pH}$ 7.2. Next,
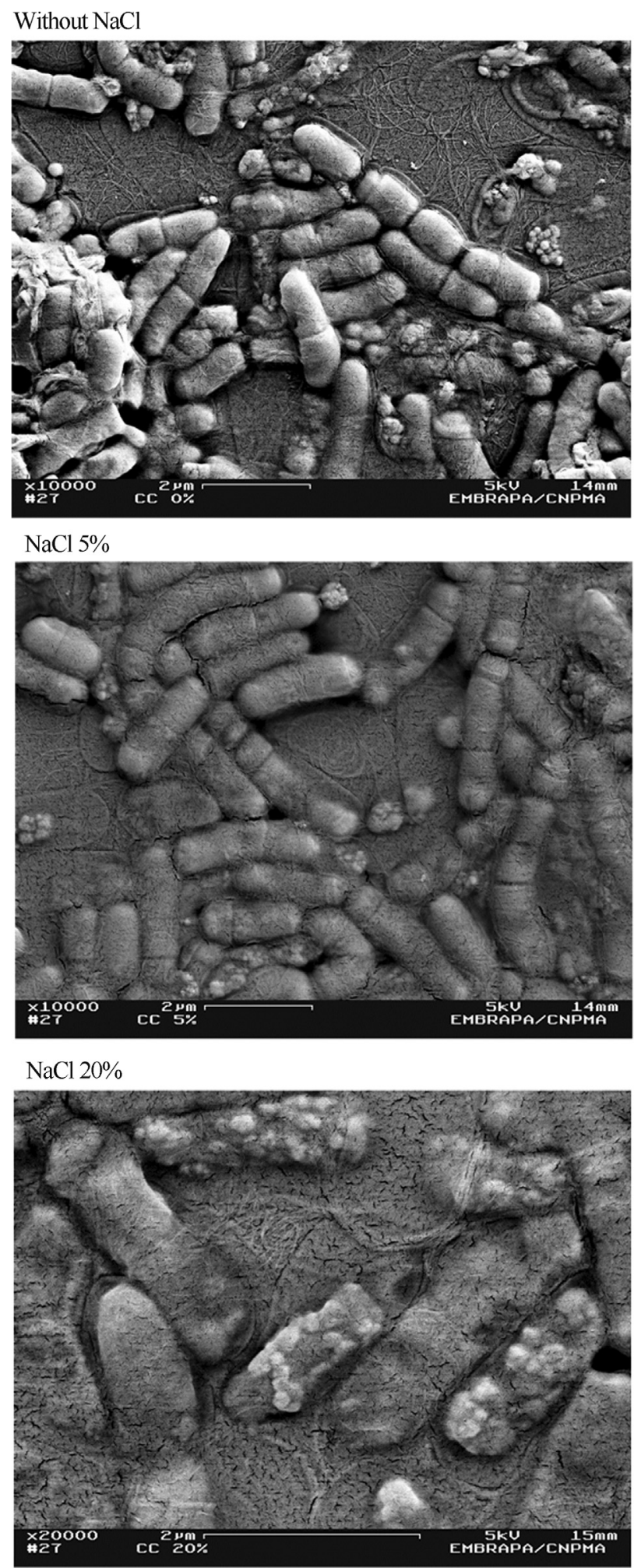

Figure 1 - Biofilm formation and cellular modifications in strain 39a ( $B a-$ cillus subtilis) cultured under distinct salinity levels (percentage of $\mathrm{NaCl}$ ). 
samples were rinsed in the same buffer and dehydrated in increasing ethanol series. A final dehydration was performed in acetone, prior to drying at critical point. Samples were then stacked in stubs and covered by a thin gold layer. The samples were observed under high-resolution with a model Leo 982 GEMINIDMS (Zeiss and Leica, Germany). The scans revealed the different biofilm formation when $\mathrm{NaCl}$ was added to the medium (Figure 1), possibly suggesting that salinity does drive the biofilm formation in the $R$. mangle rhizosphere (Figure 1). Additionally, morphological modifications to bacterial cells were identified as a response to salinity adaptation. These modifications are probably caused by accumulated solutes within cells, which can interfere in the osmotic equilibrium, and consequently in protein activity (Sleator and Hill, 2001). The images revealed the presence of endospores in cells growing at 3 and $5 \%$ salt concentrations, while at higher $\mathrm{NaCl}$ concentrations (10 to $20 \%$ ), other cellular modifications were observed, such as in cellular elongation, as described by Zahran, (1997).

In addition to endospore formation and cellular elongation, another modification in cellular physiology was biofilm formation, which was found to be related to increased $\mathrm{NaCl}$ concentrations. In this case, biofilms would act in improving the microorganisms' ability to survive under saline stress conditions, where the biofilm matrix layer covering cells may act as a barrier against to osmotic changes (Nichols et al., 2005). Such a barrier constituted by microbial biofilm is mainly composed of EPS, which is a compound partially degraded by endoglucanase activity. Assuming that, it can be inferred that regulation of freeliving or biofilm-forming Bacillus spp. in the R. mangle rhizosphere is partially driven by saline concentration in the mangrove sediment. This would explain why such bacteria are abundant in the rhizosphere of this plant, and could also show the regulatory mechanism that enables them to have an advantage in niche colonization.

In summary, this study explored the endoglucanaseproducing bacteria in the rhizosphere of the typical mangrove plant $R$. mangle, identifying them to the genus Bacillus and Paenibacillus, which are important players in degrading cellulose-like materials. In addition, the salinity level modulated the composition of cells membrane in the 39 a isolate and interfered in this bacteria's ability to produce endoglucanases and form biofilms. Thus this mechanism is indicated as a key factor in the ecology of such organisms from this niche.

\section{Acknowledgments}

This study was supported by a grant from the State of São Paulo Research Foundation (FAPESP/BIOTA 2004/13910-6). Also, A.C.F. Dias (2008/54013-8) received a graduate fellowship. We also thank the support from the Oceanographic Institute (IO, USP, São Paulo), es- pecially Dr. Ricardo P. Menghini and João Luis da Silva for their support in mangrove expeditions and samplings.

The authors declare that they have no conflict of interest.

\section{References}

Al-Sayed H; Ghanem EH; Saleh KM (2005) Bacterial community and some physico-chemical characteristics in a subtropical mangrove environment in Bahrain. Mar Pollut Bull 50:147155.

Cunha MA; Pedro R; Almeida MA; Silva MH (2005) Activity and growth efficiency of heterotrophic bacteria in a salt marsh (Ria de Aveiro, Portugal). Microbiol Res 160:279-290.

Dias ACF; Andreote FD; Dini-Andreote F; Lacava PT, Sá ALB; Melo IS; Azevedo JL; Araújo WL (2009) Diversity and biotechnological potential of culturable bacteria from Brazilian mangrove sediment. World J Microb Biot 25:1305-1311.

Dias ACF; Melo IS, Dini-Andreote F; Taketani RG, Tsai SM, Azevedo JL, Andreote FD (2011) Archaeal communities in the sediments of three contrasting Mangroves. J Soils Sediment 11:1466-1476.

Fruehaf P (2005) Rhizophora mangle (mangue vermelho) em áreas contaminadas de manguezal na Baixada Santista. Piracicaba, Brazil, 223 p. (PhD. Thesis. Escola Superior de Agricultura "Luiz de Queiroz" USP).

Holguin G, Vazquez P, Bashan Y (2001) The role of sediment microorganisms in the productivity, conservation and rehabilitation of mangrove ecosystems: an overview. Biol Fertil Soils 33:265-278.

Kaneda T (1977) Fatty acids of the genus Bacillus: an example of branched-chain preference. Bacteriol Rev 41:391-418.

Lawson EO (2011) Physico-chemical parameters and heavy metal contents of water from the mangrove swamps of Lagos Lagoon, Lagos, Nigeria. Adv Biolog Res 5:8-21.

Maciel-Souza MC, Macrae A, Volpon AGT, Ferreira PS, Mendonça-Hagler LC (2006) Chemical and microbiological characterization of mangrove sediments after a large oilspill in Guanabara Bay - RJ - Brazil. Braz J Microbiol 37:262-266.

Nichols CAM, Guezennec J, Bowman JP (2005) Bacterial exopolysaccharides from extreme marine environments with special consideration of the Southern Ocean, Sea Ice, and Deep Sea hydrothermal vents: A review. Mar Biotechnol 7:253-271.

Nicolaus B, Manca MC, Lama L, Esposito E, Gambacorta A (2001) Lipid modulation by environmental stresses in two models of extremophiles isolated from Antarctica. Polar Biol 24:1-8.

Peixoto R, Chaer GM, Carmo FL, Araújo FV, Paes JE, Volpon A, Santiago GA, Rosado AS (2011) Bacterial communities reflect the spatial variation in pollutant levels in Brazilian mangrove sediment. A Van Leeuw J Microb 99:341-354.

Pooja S, Mugeraya G (2011) Halophilic bacteria and their compatible solutes - osmoregulation and potential applications Curr Sci India 100:1516-1521.

Santos HF; Cury JC, Carmos FL, Santos AL, Tiedje J, Van Elsas JD, Rosado AS, Peixoto RS (2011) Mangrove Bacterial Diversity and the Impact of Oil Contamination Revealed by Pyrosequencing: Bacterial Proxies for Oil Pollution. PLoS One 6(3):e16943. 
Schaeffer-Novelli Y, Cintrón-Molero G, Soares MLG, De-Rosa T (2000) Brazilian Mangroves. Aquat Ecosys Health 3:561-570.

Sleator RD, Hill C (2001) Bacterial osmoadaptation: the role of osmolites in bacterial stress and virulence. FEMS Microbiol Rev 26:49-71.

Teather RM, Wood PJ (1982) Use of Congo red-polysaccharide interactions in enumeration and characterization of cellulolytic bacteria from the bovine rumen. Appl Environ Microbiol 43:777-780.

Ventosa A, Nieto JJ, Oren A (1998) Biology of moderately halophilic aerobic bacteria. Microbiol Mol Biol Rev 62:504-544.
Wirth S, Ulrich A (2002) Cellulose-degrading potencials and phylogenetic classification of Carboxymethyl-cellulose decomposing bacteria isolated from soil. System Appl Microbiol 25:584-591.

Zahran NHH (1997) Diversity, adaptation and activity of the bacterial flora in saline environments. Biol Fertil Soils 25:211-223

All the content of the journal, except where otherwise noted, is licensed under a Creative Commons License CC BY-NC. 